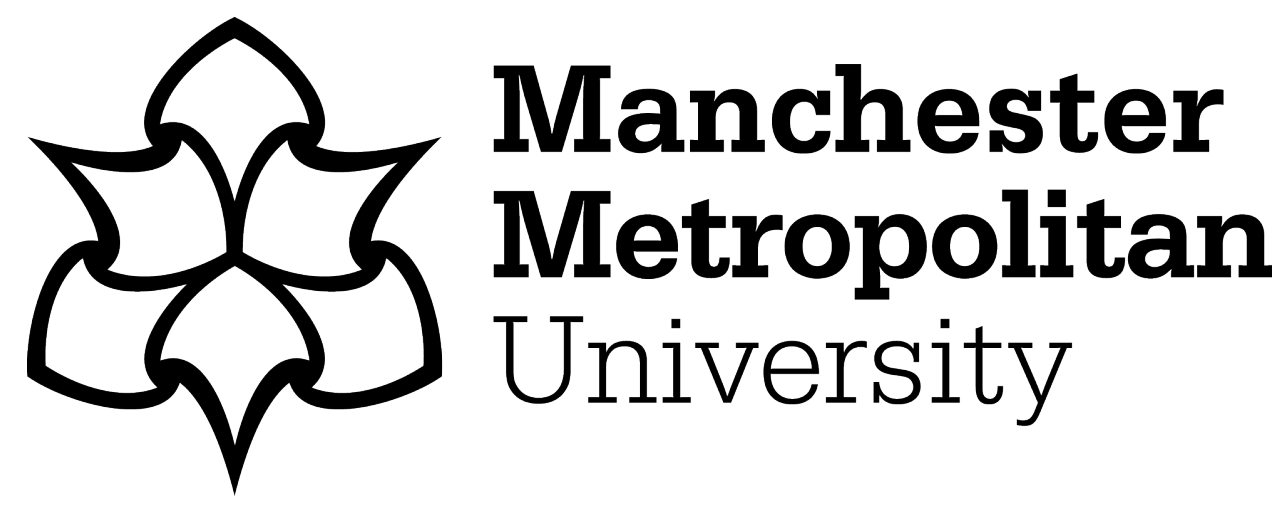

Wong, KKS (2018) Can Justice Reinvestment Deliver Social Justice? In: Routledge Handbook on Social Justice in Criminal Justice. Routledge, 711 Third Avenue, 8th Floor' New York, NY 10017. ISBN 9781138545649

Downloaded from: https://e-space.mmu.ac.uk/619083/

Version: Accepted Version

Publisher: Routledge

Please cite the published version 


\title{
JUSTICE REINVESTMENT: CAN JUSTICE REINVESTMENT DELIVER SOCIAL
}

\section{JUSTICE?}

\begin{abstract}
Justice Reinvestment is both an ideal and an approach to reducing mass incarceration. It was originally conceived of as a way of creating a more socially just criminal justice system based on reallocating prison funds to invest in high incarceration communities. Underpinning it is an explicit economic argument, centred on using evidence to make changes which will provide a better return for society than the existing criminal justice system. This article assesses the extent to which the social justice conceptualisation of Justice Reinvestment set out by Susan Tucker and Eric Cadora in 2003 has been achieved. It will examine: the development and implementation of Justice Reinvestment in the United States, United Kingdom and Australia; how the impact of Justice Reinvestment on social justice can be measured; and how it is likely to develop in the future.
\end{abstract}

\section{KEY WORDS}

Justice reinvestment, criminal justice system, social justice, prison reform, evidence based practice, economic analysis

\section{1: INTRODUCTION: WHAT IS JUSTICE REINVESTMENT?}

Since its origins in the seminal paper by Susan Tucker and Eric Cadora in $2003^{1}$, Justice Reinvestment (JR), has been advocated as a response to mass incarceration. It has become both an ideal and an approach to the delivery of a more socially just criminal justice system. Underpinning it is an explicit economic argument, centred on using data and evidence to make changes which will provide a better return for society than the existing criminal justice system. 
The term first appeared in Tucker and Cadora's article for Open Society $\left(2003^{2}\right)$. It captured the imagination of prison reform advocates with a simple but compelling argument. That it was better to re-direct funds spent on prisons to rebuilding the human, social and physical resources of neighbourhoods affected by high levels of incarceration.

Tucker and Cadora's concept of JR was based on research by Cadora and others which gave rise to the phrase which best captures the essence of JR, that of 'million dollar blocks'; city blocks in Brooklyn where a million dollars was being spent on incarcerating residents ${ }^{3}$. As a response to mass incarceration and to those communities most affected by incarceration, by default, it offered a way of addressing the disproportionate representation within prison of people from "low income neighbourhoods of color"4.

Since then, as noted by some commentators, JR has come to mean different things to different people. ${ }^{5}$ Therefore, it is worth considering in some detail, Tucker and Cadora's original vision of JR. This will be covered in the section which immediately follows. The rest of this article will examine the following:

- the extent to which this vision (for the purposes of this article) held up as the social justice ideal, has been achieved in three countries with relatively high levels of incarceration: the United States (US), the United Kingdom (UK) and Australia ${ }^{6}$;

- how social justice generated through JR can be measured drawing on learning primarily from the US and UK; and finally

- the future of JR. 


\section{2: JUSTICE REINVESTMENT AND SOCIAL JUSTICE}

Tucker and Cadora's socially inclusive vision is projected through three key themes. Firstly an explicit call for prison funding to be re-directed for non-criminal justice spending, specifically, to rebuild “...the human resources and physical infrastructure - the schools, healthcare facilities, parks and public spaces - of neighbourhoods devastated by high levels of incarceration."7. Secondly, the emphasis given to devolving accountability and responsibility to a local level, “... seeking community level solutions to community level problems" . Thirdly, a preventative approach to public safety that "...targets money for programs in education, health, job creation, and job training in low income communities." 9 Looking for preventative solutions outside the criminal justice system.

Looking beyond the US, the emphasis on community focused, place-based initiatives has been championed enthusiastically by JR proponents outside the US. In the UK, Rob Allen, an early proponent of JR argued that JR should, “...improve the prospects of not just of individual cases but of particular places," $" 10$. The argument for what in the UK is termed localism was further reinforced by the Commission on English Prisons Today ${ }^{11}$ and the UK House of Commons Justice Committee ${ }^{12}$. In Australia, arguments have also been made for trialling JR in high crime communities ${ }^{13}$ and earlier by Brown, Schwartz and Boseley as a mechanism for addressing the over-imprisonment of indigenous people ${ }^{14}$.

As a mechanism for effecting prison reform JR was intended to "...depoliticise the issue of mass incarceration" acknowledged by Susan Tucker in an interview over a decade on from the publication of the original paper ${ }^{15}$. It was acknowledged as an attractive feature by commentators such as Ross Homel, who described JR as intertwining the themes of "...a rational social policy, the intelligent use of data on the geography and sociology of crime, the futility (and, implicitly the savagery) of imprisonment as a cure all for crime and safety 
problems..."16. Fox, Albertson and Wong had also identified the potential for the economic underpinning of JR to transcend populist punitivism ${ }^{17}$. Thus, providing politicians and policy makers with a publicly acceptable justification for reducing prison populations, particularly, in the wake of the economic crises of 2007 and 2008. This was noted by Brown, Schwartz and Boseley as JR being “...compatible with various tenets of neo-liberalism.” in using economic incentives to change public policy ${ }^{18}$.

What has emerged in the last decade since Tucker and Cadora's social justice vision of JR is an approach to JR primarily, described as criminal justice system re-design ${ }^{19}$ based on delivering efficiencies within the criminal justice system rather than alternatives outside the system $^{20}$.

\section{3: JUSTICE REINVESTMENT IN PRACTICE}

This section examines the differing trajectories of JR implementation in the US, UK and Australia. It will assess, in broad terms, the extent to which implementation has followed a social justice or criminal justice system re-design model. These are not necessarily mutually exclusive and instead can be conceived of as two ends of a continuum, along which individual initiatives may be located ${ }^{21}$.

\section{1: Justice Reinvestment in the US}

The implementation of JR in the US has been both advanced and limited by the Justice Reinvestment Initiative (JRI), a federal programme which has supported the development of JR in the US. It can be considered to be advanced, because the most extensive implementation of JR has occurred in the US (compared to the UK and Australia), as a consequence of the funding provided by the Bureau of Justice Assistance to states and localities $^{22}$. However, it can also be viewed as limited in relation to upholding the social justice principles of Tucker and Cadora ${ }^{23}$, because it has largely followed a criminal justice 
system redesign model. In their review of the JR1, Austin, Cadora, Clear, Dansky, Greene, Gupta, Mauer, Porter, Tucker and Young commented that the JRI had abandoned the basic tenets of JR, specifically, the commitment to place-based strategies and reinvestment of savings in communities with high incarceration rates ${ }^{24}$. This is not to say that what has been achieved by the JRI is not laudable. In a wry comment, Mark Mauer, interviewed for their comprehensive review of JR for the book by Brown and colleagues observed that the article (referenced immediately above) which he contributed to should have been retitled, "What you are doing is good...but don't call it Justice Reinvestment"25.

In the US, JR has operated at both state and locality levels ${ }^{26}$. At a state level, through preinvestment, providing funding for programmes based on anticipated savings; and postinvestment, reinvestment of actual savings and averted spending ${ }^{27}$. At a locality level, in comparison the funding of JR, pre and post investment has been more limited ${ }^{28}$.

In their detailed analysis of JR implementation in the US, Brown and colleagues discerned two parallel developments based on administrative and jurisdictional boundaries, with the "shape" of JR determined by whether this occurred at a state or locality level'29.

At a state level, they concluded that the model operated as a:

“...political and legislative process to address over-incarceration in state controlled (and funded) prisons and is largely driven by the work of the CSG [Council for States Government]."30

This was based on the four step 'justice mapping' blue-print advocated by the Council for States Government. This requires (1) analysing prison population and public spending in the communities which prisoners return to, (2) examining the provision of options for generating savings and increases in public safety; (3) the quantification of savings and reinvestment in 
high-stakes communities; and finally (4) the measurement of impacts and evaluation of programme effectiveness ${ }^{31}$.

However, as noted by some commentators by 2011 , the four steps had narrowed to three ${ }^{32}$. The third step, the place based strategy of reinvesting savings in communities with high rates of incarceration had been removed; alongside an absence of analysing public spending in the communities which prisoners returned to ${ }^{33}$.

As noted by Brown and colleagues, "What remains is a reform program centred on consensus-driven passage of legislation aimed at a reduction in corrections expenditure without jeopardising public safety." 34 The focus on the legislative component may have helped to make reform more durable and reduce the likelihood of punitive relapses ${ }^{35}$, however, arguably it has lost the key social justice component of reinvestment in high incarceration communities.

This has not been lost on those at the forefront of promoting JR in the US. Marshall Clement, the Director of the CSG's Justice Center (interviewed for the book by Brown and colleagues ) suggested that the structural challenges inherent in the criminal justice system made it difficult to move beyond these to consideration of a more community based focused, added to which there was a lack of community development expertise ${ }^{36}$.

At a local level, the focus has been individuals incarcerated in county jails, identified as being a generally low risk, high churn population, who frequently recycled back into the criminal justice system ${ }^{37}$. Legislative action has not dominated these local initiatives, instead there has been more of a focus on working with stakeholders on the ground, at sites with a history of progressive criminal justice reform ${ }^{38}$. The opportunity for a more place based, social justice oriented approach to JR may have been more possible. In practice, the potential for 
focusing on high incarceration neighbourhoods has not been realised, with attention given instead to countywide prison populations ${ }^{39}$.

It is worth noting that three features mark out the development of JR in the US compared to the UK and Australia. Firstly, political bi-partisanship and support, arguably driven by the requirement for this to be in place in order to receive Federal financial support ${ }^{40}$. Secondly, a shift in the political narrative about crime solutions from being 'tough on crime' to being 'smart on crime', which was embraced across the political spectrum. ${ }^{41}$ Thirdly, the role of faith based organisations such as the Prison Fellowship in promoting JR through a restorative approach to justice, articulated through a redemptive agenda - giving prisoners a "second chance" and being "smart on crime". ${ }^{42}$

\section{3:2 Justice Reinvestment in the UK}

By contrast, in the UK, despite the immediate post financial crisis interest in JR by politicians and policy makers, there has been no overarching guiding force behind JR development such

as the JRI in the US. ${ }^{43}$ As a consequence, implementation has been fragmented and limited to a set of largely uncoordinated schemes, originating in different government departments - the Ministry of Justice (MoJ), Department of Health and Department of Communities and Local Government $^{44}$. In the main, JR in the UK has largely been diverted along a payment by results $(\mathrm{PbR})$ route. The two explicit JR pilot programmes commissioned by the Ministry of Justice being: the Youth Justice Custody Reinvestment Pathfinder; and Local Justice Reinvestment Pilot were PbR pilots ${ }^{45}$.

However, taking a broader view of what constitutes JR, i.e. beyond the two pilot programmes explicitly labelled as JR, Wong and Christmann identified other JR schemes in the $\mathrm{UK}^{46}$. These operated at different levels of administration - national, regional and local, working to targets ranging from specified fiscal savings, reduction in reoffending, to a basket of 
measures spanning the disparate spheres of employment, crime, child welfare, mental and physical health ${ }^{47}$. This unplanned, mixed economy of development has arguably allowed for the testing of JR solutions both inside and outside of the criminal justice system. The most significant of these outside the justice system being the Troubled Families Programme which operated in 143 English local authorities. ${ }^{48}$ However, this implicit JR initiative has been tainted by controversy ${ }^{49}$.

In the UK, while the disproportionality (of black and minority ethnic individuals) within prison and the criminal justice system (more generally) exists ${ }^{50}$. It has not been a significant feature of the discourse around JR in the UK.

While the capacity and capability to implement JR has been addressed in the US through the funding of technical assistance as part of the JRI, in the UK, the issue of capacity and capability has been largely unconsidered ${ }^{51}$.

The redemptive agenda, a key feature of JR in the US has so far played little role in the development of JR in the UK. It was given prominence in the announcements around prison reform by the then UK Prime Minister, David Cameron in February 2016 ${ }^{52}$. However, both the political interest in offering prisoners a "second chance" and the prison reforms have proved to be short-lived, kicked into the long grass by the political earthquake of the "Brexit" vote and subsequent and lasting diversion of political attention and effort to securing an exit from the European Union ${ }^{53}$.

\section{3: Justice Reinvestment in Australia}

In Australia there was support for the Commonwealth adopting a leadership role in facilitating the implementation of JR across the country ${ }^{54}$. However, this did not materialise, because of political opposition to the leadership role and then a change of government ${ }^{55}$. Instead, developments have been driven at a community level ${ }^{56}$. In broad terms, of the three 
countries considered in this article, Australia has adhered most closely to the social justice principles outlined in Tucker and Cadora's original 2003 paper. In particular, the focus on place-based initiatives and explicit commitment to addressing the disproportionate representation of indigenous people in the criminal justice system ${ }^{57}$.

The actual implementation of JR has been less extensive in Australia than either the US or UK, as noted by Brown and colleagues in their comprehensive examination of JR in the US, UK and Australia ${ }^{58}$. Nevertheless, their review of JR implementation in Australia, identified four themes which have marked out its development.

The first of these, is the community involvement aspect of the Australian pilots. The most advanced of these in Bourke, New South Wales (NSW) is community led and seeks to address the overrepresentation of Aboriginal young people in custody ${ }^{59}$.

The second, is the involvement of a range of non-governmental organisations in individual states which have consistently advocated for JR and have been actively involved in developing the pilots, such as: Just Reinvest in the Bourke pilot in NSW ${ }^{60}$; the Australian Red Cross involved in a community project in Wooribinda, Queensland ${ }^{61}$; and Smart Justice, campaigning for a youth justice reinvestment approach in the state of Victoria. ${ }^{62}$

The third, is at a state level, government and political support for JR, such as: an election commitment from the New South Wales Labor party to invest $\$ 4$ million in three JR pilots ${ }^{63}$; and the Australian Capital Territory (ACT) Government setting out a four year Justice Reinvestment strategy from 2014-18. ${ }^{64}$

The fourth and final theme are the academic projects which have developed to advocate for and inform, community, state and national developments around Justice Reinvestment. The most prominent being Brown and his colleagues - the Australian Justice Reinvestment 
Project and a project to examine reinvestment options in Cowra NSW led by Dr Gill Guthrie from the National Centre for Indigenous Studies at the Australia National University ${ }^{65}$.

\section{4: MEASURING THE IMPACT OF JUSTICE REINVESTMENT ON SOCIAL JUSTICE}

The extent to which social justice has been achieved through Justice Reinvestment has been examined by assessing the approaches adopted in the US, UK and Australia against the originating principles set out by Tucker and Cadora ${ }^{66}$. Inevitably, the development of JR across these three countries has been shaped by funding, capability and political will. Arguably, adhering to the original social justice principles is not altogether simple. If anything, the experience thus far, suggests that to achieve this requires a wider range of capabilities than is required to achieve a criminal justice redesign JR solution ${ }^{67}$.

As acknowledged by governmental bodies across all three countries ${ }^{68}$ and JR commentators ${ }^{69}$ JR is "avowedly, data-driven and evidence-based"70. Arguably, therefore the impact of JR in delivering social justice should be measurable. However, with some notable exceptions, Brown and colleagues concluded that:

"There has been limited critical analysis of what counts as evidence, the measures used and to whom they are applied..." 71

Arriving at a similar conclusion, and in the absence of a means of making comparisons between JR initiatives, Wong and Christmann (drawing on the experience of JR measurement in the US and UK) devised the following outcome and measurement framework, reproduced at Table 1.

Table 1: JR Outcome and measurement framework from Wong and Christmann ${ }^{72}$

\begin{tabular}{|l|l|}
\hline Outcomes & Measures
\end{tabular}




\begin{tabular}{|c|c|}
\hline $\begin{array}{l}\text { Reducing } \\
\text { criminality }\end{array}$ & $\begin{array}{ll}\text { - } & \text { Reduced crime rates } \\
\text { - } & \text { Reduced reoffending } \\
\text { - } & \text { Reduced demand on the criminal justice system }\end{array}$ \\
\hline Social justice & $\begin{array}{l}\text { - } \text { increased social trust and associational networks: } \\
\text { - } \quad \text { lower crime rates; } \\
\text { - } \quad \text { better health rates; } \\
\text { - } \quad \text { improved longevity; } \\
\text { - } \quad \text { better educational achievement; } \\
\text { - } \quad \text { greater levels of income equality; } \\
\text { - } \quad \text { improved child welfare; } \\
\text { - lower rates of child abuse; } \\
\text { - less corrupt and more effective government; and } \\
\text { - } \quad \text { enhanced achievement through increased trust and lower transaction costs }\end{array}$ \\
\hline $\begin{array}{l}\text { Savings realised } \\
\text { within a specified } \\
\text { time frame }\end{array}$ & $\begin{array}{l}\text { - To agencies within the criminal justice system } \\
\text { - To agencies outside the criminal justice system } \\
\text { - To wider society not covered by the other two categories }\end{array}$ \\
\hline Reinvestment & $\begin{array}{l}\text { - } \quad \text { Pre-investment - reinvestment based on projected savings } \\
\text { - } \quad \text { Post investment - reinvestment based on actual savings }\end{array}$ \\
\hline Process outcomes & $\begin{array}{l}\text { - More effective working between agencies } \\
\text { - Systematic use of evidence based practices } \\
\text { - Greater transparency and accountability in the use and reporting of data and } \\
\text { analysis }\end{array}$ \\
\hline
\end{tabular}


While this framework draws together the best of JR measurement available at the time, it is nevertheless limited by what has been developed and implemented thus far. In particular, given that to date, JR implementation has done little to encompass and address the social determinants of crime ${ }^{73}$, the framework provides a starting point for measurement and would benefit from further refinement as JR itself develops.

\section{5: CONCLUSION: THE FUTURE OF JUSTICE REINVESTMENT}

There is the potential for JR implementation to develop in a way which approaches the social justice ideal set by Tucker and Cadora ${ }^{74}$. The development of JR to date can be viewed as a journey moving from criminal justice system re-design models to a more social justice oriented iteration of JR. Reviewing what has been implemented thus far in the US, UK and Australia, there are examples of: place based initiatives; solutions outside of the criminal justice system; a focus on addressing racial disproportionality within the incarcerated populations and those within the criminal justice system more broadly. Perhaps more encouragingly, the discourse and debate around shifting JR to that social justice ideal has not abated, if anything, it is being kept alive, both by policy makers, commentators and researchers in the field ${ }^{75}$.

There is the potential for JR to develop as specific responses to vulnerable groups within the criminal justice system, such as women and girls, young people, young adults and those with mental health problems ${ }^{76}$.

In the US, the JRI has taken JR implementation along an efficiencies within the justice system direction focused on back-end measures such as parole processing, post-release support and dealing with probation and parole violations ${ }^{77}$. However, JR development at a local level (in the US) demonstrates the potential of front-end options: addressing the 
characteristics of 'frequent flyers', diverting offenders and improved case processing; and engaging agencies outside of the criminal justice system in identifying solutions ${ }^{78}$.

In the UK, formal devolution to the English regions and Police and Crime Commissioners with responsibility for countywide areas, making good on the 'and crime' part of their remit may provide an opportunity for the development of a more localised JR response in the $\mathrm{UK}^{79}$.

In Australia, the community led nature of JR development offers a template for bottom-up approaches in other jurisdictions and may be instructive in helping to shape the way in the which the social determinants of crime may be factored into a more sophisticated conceptualisation and measurement of $\mathrm{JR}^{80}$.

\section{SUMMARY}

The phrase Justice Reinvestment (JR) was used by Susan Tucker and Eric Cadora in a seminal paper published in 2003 which argued for tackling mass incarceration by diverting prison funds to rebuilding the human, social and physical resources of neighbourhoods affected by high levels of incarceration. This place-based approach was founded on the principles of using data and evidence to inform changes which were intended to create a more socially just criminal justice system. Since 2003, there has been support for this approach from prison reformers, politicians, policy makers and academics in the United States (US), United Kingdom (UK) and Australia.

The trajectory of JR implementation in these three countries has varied considerably. In the US, supported by the Bureau of Justice Assistance, JR has been driven by the Justice Reinvestment Initiative (JRI) which has led it down a criminal justice redesign approach, focusing on efficiencies within the criminal justice system. States have generally adopted a legislative route for JR based on pre-investment and post investment of resources. In localities there has been a wider engagement of stakeholders including those outside the 
justice system but JR has tended to focus on whole prison populations rather than high incarceration neighbourhoods.

In the UK, there has been a mixed economy of JR implementation characterised by being commissioned through a payment by results process. There have been JR initiatives which have operated a criminal justice system redesign approach as well as others which in aiming for solutions outside the justice system have reflected a social justice approach.

In Australia, implementation has been less extensive than the US and UK, however, the JR pilots and policy discourse here, has adhered most closely to Tucker and Cadora's vision, with place based initiatives targeting indigenous communities which are over-represented in the prison population.

The measurement of the impact of JR on social justice is nascent, with the approach proposed here being based on the best practice to date but subject to refinement as JR implementation itself develops.

There is potential for JR to contribute to creating a more social just criminal justice system and by default a more socially just society. The future development of JR in the US, UK and Australia offers the promise that this may be possible.

\section{DISCUSSION QUESTIONS}

1. How did the original conception of Justice Reinvestment intend to deliver social justice?

2. How has Justice Reinvestment developed in different jurisdictions?

3. What have been the facilitators and barriers to Justice Reinvestment and why?

4. Has Justice Reinvestment achieved the goal of social justice?

5. How may Justice Reinvestment develop in the future? 
${ }^{1}$ Tucker, S. and Cadora, E. (2003) Justice reinvestment: To invest in public safety by reallocating justice dollars to refinance education, housing, healthcare, and jobs [Monograph] Ideas for an Open Society, 3. Available at

http://www.soros.org/publications/ideas-open-society-justice-reinvestment [Accessed 2 March 2016 ]

2 ibid

3 ibid

${ }^{4}$ Tucker and Cadora Supra note 1 at 1

5 Wong, K., Fox, C., Albertson, K. (2014) Justice Reinvestment in the United Kingdom in an age of austerity. Victims and Offenders, 9:76-99, 201Copyright (C) Taylor \& Francis Group, LLC, Fox, C., Albertson, K. and Wong, K. (2013) Justice Reinvestment: Can the criminal justice system deliver more for less? London: Routledge., Brown, D., Schwartz, M.,Boseley, L. (2012) The promise of Justice Reinvestment AltLJ Vol 37:2 2012 .

${ }^{6}$ Brown, D., Cunneen, C., Schwartz, M., Stubbs, J., Young, C. (2016) Justice Reinvestment: Winding back imprisonment, Basingstoke: Palgrave MacMillan

${ }^{7}$ Tucker and Cadora Supra note 1 at 1

8 ibid

${ }^{9}$ Tucker and Cadora Supra note 1 at 4

${ }^{10}$ Allen, R. (2007) From restorative prisons to justice reinvestment in Allen, R. and Stern, V. (eds.) Justice Reinvestment - a new approach to crime and justice, pg 5, London: International Centre for Prison Studies

${ }^{11}$ Commission on English Prisons Today. (2009). Do better, do less: The report of the Commission on English Prisons Today. London: Howard League for Penal Reform.

${ }^{12}$ House of Commons Justice Committee (2010) Cutting crime: the case for justice reinvestment, London: The Stationary Office Limited. House of Commons Justice Committee (2014) Crime reduction policies - a co-ordinated approach? London, The Stationary Office Limited

${ }^{13}$ Australian Red Cross (2016) Re-thinking Justice: Vulnerability Report 2016, Carlton, Australian Red Cross

${ }^{14}$ Brown, Schwartz and Boseley Supra note 5

${ }^{15}$ In Brown, Cunneen, Schwartz, Stubbs and Young Supra note 5 at 19

${ }^{16}$ Homel, R., (2014) Justice Reinvestment as a global phenomenon, Victim and Offenders, 9:6 Taylor and Francis Group

${ }^{17}$ Fox, Albertson and Wong Supra note 5

${ }^{18}$ Brown, Schwartz and Boseley Supra note 5 at 97

${ }^{19}$ Fox, Albertson and Wong Supra note 5

${ }^{20}$ La Vigne, N.G., Neusteter, R.S., Lachman, P., Dwyer, A. and Nadeau, C.A., (2010) Justice

Reinvestment at the local Level, Planning and Implementation Guide, Washington: Urban Institute, Justice Policy Center. Lanning, T., Loader, I., Muir, R. (2011) Redesigning justice: reducing crime through justice reinvestment, London, Institute for Public Policy Research,

${ }^{21}$ Wong, Fox and Albertson Supra note 5 Fox, Albertson and Wong Supra note 5

${ }^{22}$ Brown, Cunneen, Schwartz, Stubbs and Young Supra note 5, Wong, K., Christmann, K., (2016) Justice Reinvestment: 'motherhood and apple pie?' - matching ambition to capacity and capability, Federal Sentencing Report Vol 29. No 1 page 58-67

${ }^{23}$ Tucker and Cadora Supra note 1

${ }^{24}$ Austin, J., Cadora, E., Clear, T.R., Dansky, K., Greene, J., Gupta, V., Mauer, M., Potter, N., Tucker, S., and Young, M.C., (2013) Ending Mass Incarceration: Charting a new Justice

Reinvestment, Sentencing Project

${ }^{25}$ Brown, Cunneen, Schwartz, Stubbs and Young Supra note 5 at 73

${ }^{26}$ LaVigne, N., Bieler, S., Cramer, L., Ho, H., Cybele Kotonias, Deborah Mayer, David McClure, Laura Pacifici, Erika Parks, Bryce Peterson, Samuels,, J. (2014) Justice Reinvestment Initiative State Assessment Report, Washington: Urban Institute, Justice Policy Center Cramer, L., Harvell, S., 
McClure, D., Sankar-Bergmann, A., Parks, E., (2014) The Justice Reinvestment Initiative Experiences

sfrom the Local Sites, Washington: Urban Institute, Justice Policy Center

${ }^{27}$ LaVigne et al Supra note 26

${ }^{28}$ Cramer et al Supra note 26

${ }^{29}$ Brown et al Supra note 6 at 58

${ }^{30} \mathrm{ibid}$

${ }^{31}$ Council of State Governments. (2010). Justice reinvestment overview. Accessed at

http://www.justicereinvestment.org/files/JR_overview_2010_rev.pdf, 2 November 2012

${ }^{32}$ Brown et al Supra note 6, Austin et al Supra note 24,

${ }^{33}$ Council of State Governments. (2011) Justice reinvestment - About the project,

http://justicereinvestment.org/about

${ }^{34}$ Brown et al Supra note 6 at 74

${ }^{35}$ Brown et al Supra note 6

${ }^{36}$ Brown et al Supra note 6 at 74

${ }^{37}$ Brown et al Supra note 6

38 ibid

${ }^{39}$ ibid

${ }^{40}$ (Bureau of Justice Assistance (2015)

https://www.bja.gov/programs/justicereinvestment/how_do_i_participate.html

${ }^{41}$ Brown et al Supra note 6

${ }^{42}$ Greene, E., (2017) Justice Reform: Unlocking second chances and more, Prison Fellowship

https://www.prisonfellowship.org/2017/03/justice-reform-unlocking-second-chances/ Accessed 28th August 2017

${ }^{43}$ Allen, R. (2014) Justice reinvestment: empty slogan or sustainable future for penal policy? London, Transform Justice, Allen, R (2015) Rehabilitation Devolution - how localising justice can reduce crime and imprisonment, London, Transform Justice Wong and Christmann Supra note 22

${ }^{44}$ Wong and Christmann Supra note 22

${ }^{45}$ Wong, Fox and Albertson Supra note 5

${ }^{46}$ Wong and Christmann Supra note 22

47 ibid

${ }^{48}$ This aimed to work 'turn around' the lives of 'troubled families' characterised by worklessness, children not being in school, adult and children involved in crime and anti-social behaviour and poor mental and physical health - Department of Communities and Local Government (2015) The Benefits of the Troubled Families Programme to the Taxpayer, London: Department for Communities and Local Government

49 As noted by Wong and Christmann (2016), while some UK JR initiatives have been explicitly labelled as JR interventions, others have had non-JR aims but in intent have had a JR focus.

${ }^{50}$ Lammy, D., (2016) Review of Racial Bias and BAME representation in the Criminal Justice System: A review to consider the treatment of, and outcomes for Black, Asian and Minority Ethnic (BAME) Individuals within the criminal justice system (CJS) in England and Wales

. Open letter to the UK Prime Minister

${ }^{51}$ Wong and Christmann Supra note 22

${ }^{52}$ Cameron, D (2016) Speech on prison reform given at Policy Exchange, Westminster, London, accessed at: https://www.gov.uk/government/speeches/prison-reform-prime-ministers-speech 30 May 2016

${ }^{53}$ The Prison Reform Bill announced in the Queen's speech (which sets out the legislative agenda for the UK) in 2016 was omitted in the Queen's speech following the General Election in June 2017, with eight of the twenty seven pieces of legislation related to Brexit (BBC 2017)

${ }^{54}$ Senate Legal and Constitutional Affairs Committee (2013) Value of a justice reinvestment approach to criminal justice in Australia, Commonwealth of Australia

${ }^{55}$ Brown et al Supra note 6

${ }^{56}$ Brown et al Supra note 6

${ }^{57}$ Brown, Schwartz and Boseley Supra note 5, Brown et al Supra note 6, Australian Red Cross (2016) Re-thinking Justice: Vulnerability Report 2016, Carlton, Australian Red Cross 


\footnotetext{
${ }^{58}$ Brown et al Supra note 6

${ }^{59}$ Just Reinvest (2017) Justice Reinvestment in Bourke http://www.justreinvest.org.au/justicereinvestment-in-bourke/ Accessed $31^{\text {st }}$ August 2017

${ }^{60}$ Just Reinvest Supra note 59

${ }^{61}$ Australian Red Cross Supra note 57

${ }^{62}$ Smart Justice What is the Justice Reinvestment Project?
}

http://www.smartjustice.org.au/cb_pages/justicereinvestment sjfyp.php Accessed $28^{\text {th }}$ August 2017

${ }^{63}$ The Guardian (2015) Indigenous issues largely ignored in NSW election campaign, say community https://www.theguardian.com/australia-news/2015/mar/25/indigenous-issues-largely-ignored-in-nswelection-campaign-say-community Accessed $27^{\text {th }}$ August 2017

${ }^{64}$ Australian Capital Territory Justice Reinvestment Strategy http://www.justice.act.gov.au/page/view/3829/title/justice-reinvestment-strategy Accessed $27^{\text {th }}$

${ }^{65}$ Brown et al Supra note 6

${ }^{66}$ Tucker and Cadora Supra note 1

${ }^{67}$ Brown et al Supra note 6, Wong and Christmann Supra note 22, Wong, Fox and Albertson Supra note 5

${ }^{68}$ (Council of States Government Supra note 31; House of Commons Justice Committee Supra note 12 ; Senate Legal and Constitutional Committee Supra note 54

${ }^{69}$ Allen Supra note 43, Fox, Albertson and Wong Supra Note 5, Clear, T., (2010) 'Policy and Evidence: The challenge to the American society of criminology: 2009 Presidential Address to the American Society of Criminology', Criminology, 48(1), page 1-25

${ }^{70}$ Brown et al Supra note 6 at 141

${ }^{71}$ Brown et al Supra note 6 at 143

${ }^{72}$ Wong and Christmann Supra note 22 at 64

${ }^{73}$ Fox, Albertson and Wong Supra note 5, Brown et al Supra note 6

${ }^{74}$ Tucker and Cadora Supra note 1

75 (Brown et al Supra note 6, Austin et al Supra note 24, Cadora, E., (2014) 'Civic Lessons: How Certain Schemes to End Mass Incarceration can Fail'. The Annals of the American Academy of Political and Social Science 651(6) page 277-85

${ }^{76}$ Brown et al Supra note 6, Allen, 2014, 2015, Supra note 43, Wong and Christmann Supra note 22, Wong, Fox and Albertson Supra note 5.

${ }^{77}$ Austin, J., 2011) Making imprisonment Unprofitable, Criminology and Public Policy 10(3) page 629-35

${ }^{78}$ Lachman, P., Neusteter, S.R., 2012) Tracking costs and savings through Justice Reinvestment at the Local Level Brief 1, Washington DC Urban Institute

${ }^{79}$ Fox, C., (2017) Justice Devolution: An opportunity for Greater Manchester, Metropolis, Manchester Metropolitan University Wong and Christmann Supra note 22, Allen 2015 Supra note 43 .

${ }^{80}$ Brown et al Supra note 6 